\title{
LEMAHNYA PENEGAKAN HUKUM DI INDONESIA
}

\author{
Oleh: Muhammad Adam HR
}

(IAI DDI Polewali Mandar)

E-mail: muhammadadamhr@gmail.com

\begin{abstract}
Abstrak
Sistem penegakan hukum di Indonesia masih lemah, hal tersebut terlihat dari tidak tercapainya tujuan utama dari hukum itu sendiri yaitu keadilan bagi seluruh rakyatnya. Hampir dapat dipastikan bahwa di negeri ini sangat sulit memperoleh keadilan, padahal hukum yang ada sudah disusun dengan sangat baik dan jika dijalankan dengan benar, namun kenyataan yang ada saat ini penegakan hukum runcing ke bawah tumpul ke atas. Dalam hemat saya terdapat dua faktor utama yang menyebabkan hukum belum berjalan sebagaimana mestinya. Pertama, para aparat penegak hukum yang ada belum menginternalisasikan nilainilai dari profesinya sebagai penegak hukum, sehingga masih sangat mudah diintervensi dalam penegakan hukum. Kedua adalah kurangnya kesadaran hukum masyarakat akan pentingnya mematuhi aturan hukum yang telah ditetapkan.
\end{abstract}

\section{A. Pendahuluan}

Penegakan hukum (law enforcement), merupakan suatu istilah yang mempunyai keragaman dalam definisi. Menurut Satjipto Rahardjo, penegakan hukum diartikan sebagai suatu proses untuk mewujudkan keinginan-keinginan hukum, yaitu pikiran-pikiran dari badan-badan pembuat undang-undang yang dirumuskan dan ditetapkan dalam peraturan-peraturan hukum yang kemudian menjadi kenyataan.

Penegakan hukum adalah proses dilakukannya upaya untuk tegaknya atau fungsinya norma-norma hukum secara nyata dalam masyarakat sebagai pedoman perilaku dalam 
kehidupan bermasyarakat, berbangsa, dan bernegara yang dapat dilakukan oleh subjek ${ }^{1}$ hukum dan objek ${ }^{2}$ hukum.

Ditinjau dari sudut subjeknya, penegakan hukum itu dapat dilakukan oleh subjek dalam arti yang luas dan dapat pula diartikan sebagai upaya penegakan hukum oleh subjek dalam arti yang terbatas atau sempit.

Dalam arti luas, proses penegakan hukum itu melibatkan semua subjek hukum dalam setiap hubungan hukum. Siapa saja yang menjalankan aturan normatif atau melakukan sesuatu atau tidak melakukan sesuatu dengan mendasarkan diri pada norma aturan hukum yang berlaku, berarti dia menjalankan atau menegakkan aturan hukum.

Dalam arti sempit, dari segi subjeknya itu, penegakan hukum itu hanya diartikan sebagai upaya aparatur penegakan hukum tertentu untuk menjamin dan memastikan bahwa suatu aturan hukum berjalan sebagaimana seharusnya. Dalam memastikan tegaknya hukum itu, apabila diperlukan, aparatur penegak hukum itu diperkenankan untuk menggunakan daya paksa.

1 Subjek hukum adalah manusiamanusia yang terlibat dalam upaya berfungsinya hukum sebagai mestinya

2 Objek hukum adalah.proses penegakan hukum yang ditinjau dari aspek kepatuhan terhadap aturan hukum itu sendiri atau kepatuhan kepada keadilan
Pengertian penegakan hukum itu dapat pula ditinjau dari sudut objeknya, yaitu dari segi hukumnya. Dalam hal ini, pengertiannya juga mencakup makna yang luas dan sempit.

Dalam arti luas, penegakan hukum itu mencakup pula nilai-nilai keadilan yang terkandung di dalamnya bunyi aturan formal maupun nilai-nilai keadilan yang hidup dalam masyarakat.

Tetapi, dalam arti sempit, penegakan hukum itu hanya menyangkut penegakan peraturan yang formal dan tertulis saja. Karena itu, penerjemahan perkataan law enforcement'ke dalam bahasa Indonesia dalam menggunakan perkataan 'penegakan hukum' dalam arti luas dan dapat pula digunakan istilah 'penegakan peraturan' dalam arti sempit.

Dengan uraian di atas jelaslah kiranya bahwa yang dimaksud dengan penegakan hukum itu kurang lebih merupakan upaya yang dilakukan untuk menjadikan hukum, baik dalam arti formil yang sempit maupun dalam arti materiel yang luas, sebagai pedoman perilaku dalam setiap perbuatan hukum, baik oleh para subjek hukum yang bersangkutan maupun oleh aparatur penegakan hukum yang resmi diberi tugas dan kewenangan oleh undang-undang untuk menjamin berfungsinya normanorma hukum yang terkait dengan tema penegakan hukum. 
Pembedaan antara formalitas aturan hukum yang tertulis dengan cakupan nilai keadilan yang dikandungnya ini bahkan juga timbul dalam bahasa Inggris sendiri dengan dikembangkannya istilah the rule of law' versus 'the rule of just law' atau dalam istilah 'the rule of law and not of man'versus istilah 'the rule by law' yang berarti 'the rule of man by law'.

Dalam istilah the rule of law'terkandung makna pemerintahan oleh hukum, tetapi bukan dalam artinya yang formal, melainkan mencakup pula nilai-nilai keadilan yang terkandung di dalamnya. Karena itu, digunakan istilah 'the rule of just law'.

Dalam istilah 'the rule of law and not of man' dimaksudkan untuk menegaskan bahwa pada hakikatnya pemerintahan suatu negara hukum modern itu dilakukan oleh hukum, bukan oleh orang. Istilah sebaliknya adalah 'the rule by law' yang dimaksudkan sebagai pemerintahan oleh orang yang menggunakan hukum sekedar sebagai alat kekuasaan belaka.

Penegakan hukum merupakan salah satu aspek terpenting dalam suatu negara hukum, karena dengan penegakan hukum maka tujuan hukum, yakni keadilan, kepastian hukum dan kemanfaatan akan dapat dirasakan oleh masyarakat, namun dalam faktanya kita menemukan bahwa penegakan hukum masih belum memenuhi salah satu dari tiga tujuan hukum tersebut. Sehingga penegakan hukum yang guna meningkatkan ketertiban dalam masyarakat masih belum tercapai.

Kajian secara sistematis terhadap penegakan hukum dan keadilan secara teoritis dinyatakan efektif apabila 5 pilar hukum berjalan baik yakni: instrument hukumnya, aparat penegak hukumnya, faktor warga masyarakatnya yang terkena lingkup peraturan hukum, faktor kebudayaan atau legal culture, faktor sarana dan fasilitas yang dapat mendukung pelaksanaan hukum.

Hikmahanto Juwana menyatakan di Indonesia secara tradisional institusi hukum yang melakukan penegakan hukum adalah kepolisian, kejaksaan, badan peradilan dan advokat. Di luar institusi tersebut masih ada diantaranya, Direktorat Jenderal Bea Cukai, Direktorak Jenderal Pajak, Direktorat Jenderal Imigrasi. Problem dalam penegakan hukum meliputi hal: ${ }^{3}$

1. Problem pembuatan peraturan perundan-gundangan.

2. Masyarakat pencari kemenangan bukan keadilan.

3. Uang mewarnai penegakan hukum.

4. Penegakan hukum sebagai komoditas politik, penegakan hukum yang diskriminatif.

3 Hikmahanto Juwono, 2006, Penegakan hokum dalam kajian Law and development :Problem dan fundamen bagi Solusi di Indonesia, Jakarta : Varia Peradilan No. 244, hlm. 13 
5. Lemahnya sumber daya manusia.

6. Advokat tahu hukum versus advokat tahu koneksi.

7. Keterbatasan anggaran.

8. Penegakan hukum yang dipicu oleh media masa.

\section{B. Pembahasan}

\section{Arti Penegakan Hukum}

Liliana Tedjosaputro, menyatakan bahwa penegakan hukum tidak hanya mencakup law enforcement tetapi juga peace maintenance, oleh karena penegakan hukum merupakan proses penyerasian antara nilai-nilai, kaidah-kaidah dan pola perilaku nyata, yang bertujuan untuk mencapai

kedamaian dan keadilan (2003:66).

Tugas utama penegakan hukum, adalah untuk mewujudkan keadilan, karenanya dengan penegakan hukum itulah hukum menjadi kenyataan (Liliana, 2003: 66). Tanpa penegakan hukum, maka hukum tak ubahnya hanya merupakan rumusan tekstual yang tidak bernyali, yang oleh Achmad Ali biasa disebut dengan hukum yang mati.

Untuk membuat hukum menjadi hidup harus ada keterlibatan nyata oleh manusia untuk merefleksikan hukum itu dalam sikap dan perilaku nyata yang konkrit. Tanpa cara demikian maka hukum tertidur pulas dengan nyenyak yang kemungkinannya hanya menghasilkan mimpi-mimpi. Karena itu tidak ada cara lain agar hukum dapat ditegakkan maka perlu pencerahan pemahaman hukum bahwa sesungguhnya hukum itu tidak lain adalah sebuah pilihan keputusan, sehingga ketika salah memilih keputusan dalam sikap dan perilaku konkrit, maka berpengaruh buruk terhadap penampakan hukum di ranah empiris.

Penegakan hukum merupakan pusat dari seluruh "aktivitas kehidupan" hukum yang dimulai dari perencanaan hukum, pembentukan hukum, penegakan hukum dan evaluasi hukum. Penegakan hukum pada hakikatnya merupakan interaksi antara berbagai perilaku manusia yang mewakili kepentingan-kepentingan yang berbeda dalam bingkai aturan yang telah disepakati bersama. Oleh karena itu, penegakan hukum tidak dapat semata-mata dianggap sebagai proses menerapkan hukum sebagaimana pendapat kaum legalistik. Namun proses penegakan hukum mempunyai dimensi yang lebih luas daripada pendapat tersebut, karena dalam penegakan hukum akan melibatkan dimensi perilaku manusia. Dengan pemahaman tersebut maka kita dapat mengetahui bahwa problemaproblema hukum yang akan selalu menonjol adalah problema "law in action" bukan pada "law in the books". 
Bahkan penegakan hukum dalam arti yang lebih luas lagi, termasuk kegiatan penegakan hukum yang mencakup segala aktivitas, yang bermaksud agar hukum sebagai perangkat kaidah normatif yang mengatur dan mengikat para subyek hukum dalam segala aspek kehidupan bermasyarakat dan bernegara benarbenar ditaati, dan sungguh-sungguh dijalankan sebagaimana mestinya (Jimly, 2008: 22).

Dalam arti sempit, penegakan hukum menyangkut kegiatan penindakan terhadap setiap pelanggaran atau penyimpangan terhadap peraturan perundangundangan, khususnya yang lebih sempit lagi, melalui proses peradilan pidana yang melibatkan peran aparat kepolisian, kejaksaan, advokat dan badan-badan peradilan.

Sudikno

Mertokusumo (2005:160), menyatakan bahwa untuk memfungsikan hukum secara nyata, maka harus dilakukan penegakan hukum, oleh karena dengan jalan itulah maka hukum menjadi kenyataan dan dalam kenyataan hukum harus mencerminkan kepastian hukum (rechtssicherheit), kemanfaatan (zweckmassigkeit) dan keadilan (gerechtigkeit).

Demi penegakan supremasi hukum, maka penegakan hukum tidak boleh ditawar-tawar yang dalam implementasinya tetap harus dengan cara-cara mencerminkan nilai-nilai kemanusian. Oleh karena itu hukum harus difungsikan sebagai sarana memanusiakan manusia, bukan justru dengan cara yang bertentangan dengan nilai-nilai kemanusiaan bahkan perampasan hak asasi manusia.

Dalam proses penegakan hukum tersebut, salah satu faktor yang mempengaruhi baik atau tidaknya proses penegakan hukum adalah penegak hukum itu sendiri, yakni pihak-pihak yang membentuk maupun menerapkan hukum (Soekanto, 1983: 5). Kompetensi polisi sebagai pintu gerbang proses penegakan hukum menjadi tumpuan untuk mewujudkan proses penegakan hukum yang menjunjung tinggi kepastian hukum, keadilan, dan kemanfaatan.

Berbicara mengenai kompetensi polisi, maka tidak dapat dilepaskan dari sumber daya manusia (SDM) kepolisian itu sendiri. Kompetensi kerja yang kurang memadai, mendorong tindakan koruptif oleh personil polisi, sehingga di samping fokus pada pembenahan standar kesejahteraan, Polri juga seharusnya menaruh keseriusan yang sama pada area penguatan kompetensi kerja para personilnya (Amriel, 2010). Profesionalisme polisi saat ini memang perlu untuk dievaluasi, karena polisi belum mampu bekerja secara profesional, dalam artian meningkatkan kemampuan dalam 
menangani pekerjaan kepolisian, dan yang dapat dilakukan dengan cara mendekatkan polisi kepada dunia pendidikan sebagai sarana meningkatkan kemampuannya dalam rangka untuk meningkatkan ilmu pengetahuan dan teknologi (Nawawi, 2010: 61).

Lawrence M. Friedman mengemukakan bahwa efektif dan berhasil tidaknya penegakan hukum tergantung tiga unsur sistem hukum, yakni struktur hukum (struktur of law), substansi hukum (substance of the law) dan budaya hukum (legal culture). Struktur hukum menyangkut aparat penegak hukum, substansi hukum meliputi perangkat perundang-undangan dan budaya hukum merupakan hukum yang hidup (living law) yang dianut dalam suatu masyarakat.

Tentang struktur hukum Friedman menjelaskan (Lawrence M. Friedman, 1984 : 5-6): “To begin with, the legal sytem has the structure of a legal system consist of elements of this kind: the number and size of courts; their jurisdiction ...Strukture also means how the legislature is organized ...what procedures the police department follow, and so on. Strukture, in way, is a kind of crosss section of the legal system... a kind of still photograph, with freezes the action."

Struktur dari sistem hukum terdiri atas unsur berikut ini, jumlah dan ukuran pengadilan, yurisdiksinnya (termasuk jenis kasus yang berwenang mereka periksa), dan tata cara naik banding dari pengadilan ke pengadilan lainnya. Struktur juga berarti bagaimana badan legislative ditata, apa yang boleh dan tidak boleh dilakukan oleh presiden, prosedur ada yang diikuti oleh kepolisian dan sebagainya. Jadi struktur (legal struktur) terdiri dari lembaga hukum yang ada dimaksudkan untuk menjalankan perangkat hukum yang ada.

Struktur adalah Pola yang menunjukkan tentang bagaimana hukum dijalankan menurut ketentuan-ketentuan formalnya. Struktur ini menunjukkan bagaimana pengadilan, pembuat hukum dan badan serta proses hukum itu berjalan dan dijalankan.

Di Indonesia misalnya jika kita berbicara tentang struktur sistem hukum Indonesia, maka termasuk di dalamnya struktur institusi-institusi penegakan hukum seperti kepolisian, kejaksaan dan pengadilan (Achmad Ali, 2002 : 8).

Substansi hukum menurut Friedman adalah (Lawrence M. Friedman, Op.cit) :"Another aspect of the legal system is its substance. By this is meant the actual rules, norm, and behavioral patterns of people inside the system ...the stress here is on living law, not just rules in law books".

Aspek lain dari sistem hukum adalah substansinya. Yang 
dimaksud dengan substansinya adalah aturan, norma, dan pola perilaku nyata manusia yang berada dalam system itu. Jadi substansi hukum menyangkut peraturan perundang-undangan yang berlaku yang memiliki kekuatan yang mengikat dan menjadi pedoman bagi aparat penegak hukum.

Sedangkan mengenai budaya hukum, Friedman berpendapat : "The third component of legal system, of legal culture. By this we mean people's attitudes toward law and legal system their belief ...in other word, is the climinate of social thought and social force wicch determines how law is used, avoided, or abused".

Kultur hukum menyangkut budaya hukum yang merupakan sikap manusia (termasuk budaya hukum aparat penegak hukumnya) terhadap hukum dan sistem hukum. Sebaik apapun penataan struktur hukum untuk menjalankan aturan hukum yang ditetapkan dan sebaik apapun kualitas substansi hukum yang dibuat tanpa didukung budaya hukum oleh orang-orang yang terlibat dalam sistem dan masyarakat maka penegakan hukum tidak akan berjalan secara efektif.

Hukum sebagai alat untuk mengubah masyarakat atau rekayasa sosial tidak lain hanya merupakan ide-ide yang ingin diwujudkan oleh hukum itu. Untuk menjamin tercapainya fungsi hukum sebagai rekayasa masyarakat ke arah yang lebih baik, maka bukan hanya dibutuhkan ketersediaan hukum dalam arti kaidah atau peraturan, melainkan juga adanya jaminan atas perwujudan kaidah hukum tersebut ke dalam praktek hukum, atau dengan kata lain, jaminan akan adanya penegakan hukum (law enforcement) yang baik (Munir Fuady, 2003 : 40). Jadi bekerjanya hukum bukan hanya merupakan fungsi perundang-undangannya belaka, malainkan aktifitas birokrasi pelaksananya (Acmad Ali, 2002 : 97).

Hal tersebut menjadi sangat relevan jika dikaitkan dengan wacana kekinian, yang mana pembentukan hukum yang dihasilkan dari proses legislasi, cenderung bersifat elitis, artinya berpihak pada kepentingan elit daripada kepentingan rakyat (Sufriadi, 2010: 235). Sebagaimana dianut dalam perspektif Marxisme, hukum dibuat tidak untuk melindungi kepentingan seluruh masyarakat, tapi untuk melindungi kepentingan kelompok elit dalam melakukan kegiatan bisnis, dan alat penguasa untuk mempertahankan kekuasaannya (Luthan, 2007: 175). Hukum perundang-undangan yang elitis demikian, apabila diterapkan dalam tradisi berpikir legalpositivism; yang memandang hukum hanya sebatas pada lingkaran peraturan perundang-undangan dan yang melakukan pemaknaan perundang-undangan secara formal- 
tekstual; tanpa mengindahkan nilainilai sosial dalam masyarakat, maka yang akan terjadi adalah penegakan hukum dalam tataran empirik akan memihak kepada kepentingan elit, bukan kepada kepentingan rakyat banyak, sehingga tujuan hukum untuk mewujudkan keadilan akan semakin jauh dari apa yang diharapkan (Sufriadi, 2010: 235).

Akhir-akhir ini apa yang dipertontonkan oleh elit-elit negara semakin nampak kebenaran apa yang telah disamapaikan oleh Luthan bahwa hukum hanya menjadi alat untuk melindungi kepentingan bisnis, dan alat penguasa untuk mempertahankan kekuasaan. Hemat saya semua itu terjadi karena para penegak hukum telah melepaskan diri dari nilai dan moral, yang akibat ulahnya memperpanjang daftar presedent buruk penegakan hukum di negeri ini. Saya sangat sepakat dengan apa yang dikataka oleh Mahfud MD (Ketua Mahkamah Konstitusi RI), bahwa praktek jual beli hukum selamanya akan tetap terjadi jika para sarjana hukum yang bertindak sebgai hakim, pilisi, jaksa dan advokat tidak memiliki moral yang baik.

Faktor-faktor yang Mempengaruhi Penegakan Hukum di Indonesia

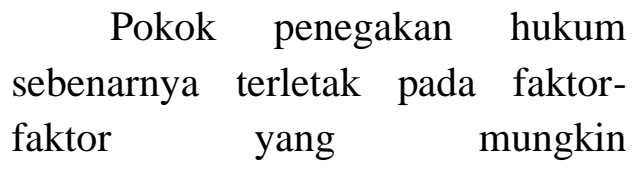

mempengaruhinya. Faktor-faktor tersebut mempunyai arti yang netral, sehingga dampak positif atau negatifnya terletak pada isi faktorfaktor tersebut.

Faktor-faktor tersebut adalah, sebagai berikut:

1. Faktor hukumnya sendiri, dalam hal ini dibatasi pada undangundang saja.

2. Faktor penegak hukum, yakni pihak-pihak yang membentuk maupun menerapkan hukum.

3. Faktor sarana atau fasilitas yang mendukung penegakan hukum.

4. Faktor masyarakat, yakni lingkungan dimana hukum tersebut berlaku atau diterapkan.

5. Faktor kebudayaan, yakni sebagai hasil karya, cipta, dan rasa yang didasarkan pada karsa manusia di dalam pergaulan hidup.

Kelima faktor tersebut saling berkaitan dengan eratnya, oleh karena merupakan esensi dari penegakan hukum, juga merupakan tolak ukur daripada efektivitas penegakan hukum. Dengan demikian, maka kelima faktor tersebut akan dibahas lebih lanjut dengan mengetengahkan contohcontoh yang diambil dari kehidupan masyarakat Indonesia.

1. Undang-undang

Undang-undang dalam arti materiel adalah peraturan tertulis yang berlaku umum dan dibuat oleh Penguasa Pusat maupun 
Daerah yang sah (Purbacaraka \& Soerjono Soekanto, 1979).

Mengenai berlakunya undang-undang tersebut, terdapat beberapa asas yang tujuannya adalah agar undang-undang tersebut mempunyai dampak yang positif. Asas-asas tersebut antara lain (Purbacaraka \& Soerjono Soekanto, 1979):

a. Undang-undang tidak berlaku surut.

b. Undang-undang yng dibuat oleh penguasa yang lebih tinggi,

c. Mempunyai kedudukan yang lebih tinggi pula.

d. Undang-undang yang bersifat khusus menyampingkan undang-undang yang bersifat umum, apabila pembuatnya sama.

e. Undang-undang yang berlaku belakangan, membatalkan undang-undang yang berlaku terdahulu.

f.Undang-undang tidak dapat diganggu gugat.

g. Undang-undang merupakan suatu sarana untuk mencapai kesejahteraan spiritual dan materiel bagi masyarakat maupun pribadi, melalui pelestarian ataupun pembaharuan (inovasi).

2. Penegak Hukum

Penegak hukum merupakan golongan panutan dalam masyarakat, yang hendaknya mempunyai kemampuan- kemampuan tertentu sesuai dengan aspirasi masyarakat. Mereka harus dapat berkomunikasi dan mendapat pengertian dari golongan sasaran, disamping mampu menjalankan atau membawakan peranan yang dapat diterima oleh mereka.

Ada beberapa halangan yang mungkin dijumpai pada penerapan peranan yang seharusnya dari golongan sasaran atau penegak hukum, Halanganhalangan tersebut, adalah:

a. Keterbatasan kemampuan untuk menempatkan diri dalam peranan pihak lain dengan siapa dia berinteraksi.

b. Tingkat aspirasi yang relatif belum tinggi.

c. Kegairahan yang sangat terbatas untuk memikirkan masa depan, sehingga sulit sekali untuk membuat proyeksi.

d. Belum ada kemampuan untuk menunda pemuasan suatu kebutuhan tertentu, terutama kebutuhan materiel.

e. Kurangnya daya inovatif yang sebenarnya merupakan pasangan konservatisme.

Halangan-halangan tersebut dapat diatasi dengan membiasakan diri dengan sikapsikap, sebagai berikut:

a. Sikap yang terbuka terhadap pengalaman maupun penemuan baru. 
b. Senantiasa siap untuk menerima perubahan setelah menilai kekurangan yang ada pada saat itu.

c. Peka terhadap masalahmasalah yang terjadi di sekitarnya.

d. Senantiasa mempunyai informasi yg selengkap mungkin mengenai pendiriannya.

e. Orientasi ke masa kini dan masa depan yang sebenarnya merupakan suatu urutan.

f.Menyadari akan potensi yang ada dalam dirinya.

g. Berpegang pada suatu perencanaan dan tidak pasrah pada nasib.

h. Percaya pada kemampuan ilmu pengetahuan dan teknologi di dalam meningkatkan kesejahteraan umat manusia.

i.Menyadari dan menghormati hak, kewajiban, maupun kehormatan diri sendiri dan pihak lain.

j.Berpegang teguh pada keputusan-keputusan yang diambil atas dasar penalaran dan perhitingan yang mantap.

\section{Faktor Sarana atau Fasilitas}

Tanpa adanya sarana atau fasilitas tertentu, maka tidak mungkin penegakan hukum akan berjalan dengan lancar. Sarana atau fasilitas tersebut antara lain, mencakup tenaga manusia yang berpendidikan dan terampil, organisasi yang baik, peralatan yang memadai, keuangan yang cukup, dan seterusnya.

4. Faktor Masyarakat

Penegakan hukum berasal dari masyarakat, dan bertujuan untuk mencapai kedamaian dalam masyarakat. Oleh karena itu, dipandang dari sudut tertentu, maka masyarakat dapat mempengaruhi penegakan hukum tersebut.

Masyarakat Indonesia mempunyai kecenderungan yang besar untuk mengartikan hukum dan bahkan mengidentifikasikannya dengan petugas (dalam hal ini penegak hukum sebagai pribadi). Salah satu akibatnya adalah, bahwa baik buruknya hukum senantiasa dikaitkan dengan pola perilaku penegak hukum tersebut.

5. Faktor Kebudayaan

$$
\text { Kebudayaan }
$$

(system) hukum pada dasarnya mencakup nilai-nilai yang mendasari hukum yang berlaku, nilai-nilai yang merupakan konsepsi abstrak mengenai apa yang dianggap baik (sehingga ditaati) dan apa yang dianggap buruk (sehingga dihindari). Pasangan nilai yang berperan dalam hukum, adalah sebagai berikut (Purbacaraka and Soerjono soekanto):

a. Nilai ketertiban dan nilai ketentraman. 
b. Nilai jasmani/kebendaan dan nilai rohani/keakhlakan.

c. Nilai kelanggengan/konservatisme dan nilai kebaruan/inovatisme.

\section{Simpulan}

Penegakan hukum adalah proses dilakukannya upaya untuk tegaknya atau berfungsinya normanorma hukum secara nyata sebagai pedoman perilaku dalam lalu lintas atau hubunganhubungan hukum dalam kehidupan bermasyarakat dan bernegara.

Aparatur penegak hukum mencakup pengertian mengenai institusi penegak hukum dan aparat (orangnya) penegak hukum. Dalam arti sempit, aparatur penegak hukum yang terlibat dalam proses tegaknya hukum itu, dimulai dari saksi, polisi, penasehat hukum, jaksa, hakim, dan petugas sipir pemasyarakatan.

Efektif tidaknya penegakan hukum tergantung tiga unsur sistem hukum, yakni struktur hukum (struktur of law), substansi hukum (substance of the law) dan budaya hukum (legal culture). Dan yang paling penting adalah menghadirkan nilai dan moral dalam penegakan hukum demi terciptanya keadilan, kepastian dan kemanfaatan hukum.

\section{DAFTAR PUSTAKA}

Ali, Achmad, Keterpurukan Hukum di Indonesia, Chalia Indonesia, Jakarta. 2002

Amriel, Reza Indragiri, Polisi Bukan Manusia, Membentuk Polisi Santun dan Berempati, Serat Alam Media, Tangerang. 2014

Asshiddiqie, Jimly, Pokok-Pokok Hukum Tata Negara Indonesia Pasca Reformasi, PT. Buana Indah Populer, Jakarta, 2008

Fuady, Munir, Aliran Hukum Kritis: Paradigma

Ketidakberdayaan Hukum, Citra Aditya, Bandung. 2003

Juwono, Hikmahanto, Penegakan Hukum Dalam kajian Law and Development: Problem dan Fundamen bagi Solusi di Indonesia. Varia Peradilan No. 244, Jakarta. 2006

Lawrence M. Friedman, American Law, New York: W.W. Norton and Company, 1984.

Luthan, Salman, Hubungan Hukum dan Kekuasaan. Jurnal Hukum, Volume 14 No. 2 Tahun 2007 
Mertokusumo, Sudikno, Mengenal

Hukum Suatu Pengantar, liberty, Yogyakarta. 2005

Nawawi, K, Progresivitas Polisi Menuju Polisi Profesional. Jurnal Ilmu Hukum Inovatif, Volume 2 No. 3 Tahun 2010

Purbacaraka, Purnadi dan Soerjono Soekanto. Sendi-Sendi Ilmu Hukum dan Tata Hukum. Alumni. Bandung.

Soekanto, Soerjono. Faktor-Faktor yang Mempengaruhi Penegakan Hukum. Jakarta: Rajawali Press. 1983

Sufriadi, Yanto. Penerapan Hukum Progresif dalam Penegakan Hukum di Tengah Krisis Demokrasi. Jurnal Hukum, Volume 17 No.2 Tahun 2010

Tedjosaputro, Liliana, Etika profesi dan profesi hukum, Aneka Ilmu, Semarang, 2003 